\title{
Docetaxel induces Bcl-2- and pro-apoptotic caspase-independent death of human prostate cancer DU145 cells
}

\author{
TAKEHARU OGURA ${ }^{1}$, YOSHIYUKI TANAKA ${ }^{1}$, HIROKI TAMAKI $^{2}$ and MAMORU HARADA ${ }^{3}$ \\ ${ }^{1}$ Biological Research Department, Sawai Pharmaceutical Co., Ltd., Osaka; ${ }^{2}$ Department of Pharmacy, \\ Shimane University Hospital; ${ }^{3}$ Department of Immunology, Shimane University Faculty of Medicine, Shimane, Japan
}

Received February 9, 2016; Accepted March 18, 2016

DOI: $10.3892 /$ ijo.2016.3482

\begin{abstract}
Docetaxel is a useful chemotherapeutic agent for the first-line treatment of hormone-refractory prostate cancer. Abnormal expression of Bcl-2 is commonly found in cancer cells, which increases their anti-apoptotic potency and chemoresistance. We investigated the effects of $\mathrm{Bcl}-2$ expression status on the susceptibility of DU145 cells, an androgenindependent human prostate cancer cell line, to docetaxel and other anticancer agents. A panel of Bcl-2-expressing DU145 cell lines was established. Bcl-2 expression levels were unrelated to the susceptibility of DU145 cells to docetaxel. The sensitivity of DU145 cells to cisplatin fluctuated, and the sensitivity to tumor necrosis factor (TNF)- $\alpha$ was decreased by Bcl-2 overexpression. In a xenograft mouse model, overexpression of Bcl-2 drastically decreased the sensitivity of DU145 cells to cisplatin and TNF- $\alpha$; however, there was no change in the response to docetaxel. Fluorescent microscopy revealed that Bcl-2-overexpression had no effect on the docetaxelinduced death of DU145 cells, but significantly decreased DU145 cell death induced by cisplatin or TNF- $\alpha$. Interestingly, docetaxel hardly induced caspase-3/7 activation in control or Bcl-2-overexpressing DU145 cells, but did at a low level in LNCaP cells, another prostate cancer cell line. Moreover, in contrast to $\mathrm{LNCaP}$ cells, the reduced viabilities of docetaxeltreated control and Bcl-2-overexpressing DU145 cells were not restored by the addition of either a Bid inhibitor or a panel of pro-apoptotic caspase inhibitors. These findings indicate that the antitumor effects of docetaxel on DU145 cells are independent of both Bcl-2 and pro-apoptotic caspases.
\end{abstract}

\section{Introduction}

Prostate cancer is one of the most common cancers among males $(1,2)$. The development and progression of prostate

Correspondence to: Dr Takeharu Ogura, Biological Research Department, Sawai Pharmaceutical Co., Ltd., 2-30 Miyahara 5-chome, Yodogawa-Ku, Osaka 532-0003, Japan

E-mail: t.ogura@sawai.co.jp

Key words: docetaxel, Bcl-2, prostate cancer, cytotoxicity, caspase cancer are closely related to androgen-receptor activation $(3,4)$. Thus, prostate cancer is generally dependent on androgen and responds to initial androgen-ablation therapy $(5,6)$. Although androgen ablation therapy leads to remissions lasting 2 to 3 years, androgen-independent cancer develops in the majority of patients. Regrettably, there was only slightly effective therapy for such patients. In 2004, however, two large randomized clinical trials showed that docetaxel-based regimens palliate symptoms and prolong survival in hormone-refractory prostate cancer $(7,8)$. Subsequently, docetaxel-based regimens have been used as the best chemotherapy for prostate cancer $(9,10)$. Moreover, the recent E3805 CHAARTED trial showed that the addition of docetaxel to standard androgen-ablation therapy extended the survival of patients with newly diagnosed metastatic hormone-sensitive prostate cancer by 13 months (11). Docetaxel is thus considered a very useful anticancer agent for the management of prostate cancer.

Most anticancer chemotherapeutic drugs, including docetaxel, primarily act by inhibiting proliferation and inducing apoptosis of cancer cells $(12,13)$. Docetaxel binds to $\beta$-tubulin and stabilizes microtubules, resulting in G2/M cellcycle arrest with aberrant mitosis. Along with G2/M arrest, taxanes induce apoptosis via activation of the extrinsic and intrinsic death pathways (14-16). Bcl-2 family proteins play crucial roles in the intrinsic pathway. The members of the Bcl-2 family can be broadly divided into anti-apoptotic and proapoptotic groups. Bcl-2 family members regulate the release of cytochrome $c$ from mitochondria, resulting in activation of executioner caspases (17). Activation of transmembrane death receptors initiates the extrinsic pathway, which is efficiently amplified by the intrinsic pathway mediated by a pro-apoptotic Bcl-2 family member, Bid (18-20). Bid is cleaved to tBid by activated caspase- 8 ; $\mathrm{tBid}$ is then translocated to mitochondria, where it promotes cytochrome $c$ release by interacting with Bax and Bak $(21,22)$. Anti-apoptotic members, such as Bcl-2 and Bcl-xL, bind to pro-apoptotic members, such as $\mathrm{Bax}, \mathrm{Bad}$, or Bid, to rescue cells from apoptosis (23). Bcl-2 and related anti-apoptotic proteins are frequently upregulated in many types of cancer (24), including prostate cancer $(25,26)$. Because of their anti-apoptotic potency, the relation between Bcl-2 overexpression and chemoresistance of cancer cells has been argued frequently $(24,27,28)$. However, in the case of taxanes such as docetaxel and paclitaxel, the relation between $\mathrm{Bcl}-2$ overexpression and chemoresistance remains 
controversial. For instance, Inoue et al showed that Bcl-2 overexpression enhances in vitro sensitivity to docetaxel in non-small cell lung cancer (29).

The aim of this study was to elucidate the roles of Bcl-2 status in the death of DU145 cells, an androgen-independent human prostate cancer cell line, after treatment with a panel of anticancer drugs, including docetaxel. For this purpose, we established a panel of DU145 transfectants that express various levels of Bcl-2 and examined their susceptibility to anticancer drugs. We also determined whether pro-apoptotic caspases participate in the docetaxel-induced death of DU145 cells.

\section{Materials and methods}

Cell lines and drugs. DU145 cells, an androgen-independent human prostate cancer cell line (ATCC, Manassas, VA, USA), were cultured in Dulbecco's modified Eagle's minimal essential medium with high glucose (Sigma-Aldrich, St. Louis, MO, USA) supplemented with $10 \%$ fetal bovine serum (FBS, Life Technologies ${ }^{\mathrm{TM}}$, Carlsbad, CA, USA). LNCaP cells, clone FGC, an androgen-dependent human prostate cancer cell line (RIKEN Cell Bank, Tsukuba, Japan), were cultured in RPMI-1640 (Sigma-Aldrich) supplemented with 10\% FBS. Cells were incubated at $37^{\circ} \mathrm{C}$ in a humidified atmosphere containing $95 \%$ air and $5 \% \mathrm{CO}_{2}$.

Docetaxel, paclitaxel, carboplatin, epirubicin, and gemcitabine were purchased from Sawai Pharmaceutical (Osaka, Japan). Doxorubicin was purchased from Kyowa Hakko Kirin (Tokyo, Japan). Cisplatin and 5-fluorouracil were purchased from Sigma-Aldrich. Human recombinant tumor necrosis factor- $\alpha$ (TNF- $\alpha$ ) was purchased from Wako Pure Chemicals (Osaka, Japan).

Establishment of Bcl-2-expressing stable transfectants. OmicsLink $^{\mathrm{TM}}$ Expression Clones for transcript variant $\alpha$ of Bcl-2 (EX-H3307-M02) and control vector (EX-NEG-M02) were purchased from GeneCopoeia (Germantown, MD, USA). DU145 cells were transfected using a combination of Nupherin $^{\text {TM }}$ (Enzo Life Sciences, Farmingdale, NY, USA) and Lipofectamine ${ }^{\circledR} 2000$ (Life Technologies) when the cells reached $70-80 \%$ confluence in 24 -well plates. First, $1 \mu \mathrm{g}$ of plasmid DNA was mixed with $10 \mu \mathrm{g}$ of Nupherin in $150 \mu \mathrm{l}$ of Opti-MEM ${ }^{\circledR}$ (Life Technologies) for $15 \mathrm{~min}$ and then combined with $150 \mu \mathrm{l}$ of Opti-MEM containing 1-4 $\mu \mathrm{l}$ of Lipofectamine 2000 for another $40 \mathrm{~min}$ at room temperature. The culture media were replaced with the transfection media, and the cells were briefly centrifuged at $100 \mathrm{x} \mathrm{g}$ and incubated for $4 \mathrm{~h}$. The transfection media were then replaced with $1 \mathrm{ml}$ of culture media. After overnight culture, the cells were subcultured in F25 flasks with culture media containing $500 \mu \mathrm{g} / \mathrm{ml}$ of $\mathrm{G} 418$. The transfected cells were then cloned by limiting dilution under G418 selection and were passaged many times $(>20)$ to develop stable cell lines.

Flow cytometry. Expression levels of Bcl-2 protein in transfectants were examined by intracellular flow cytometry. Briefly, cells fixed in $1.5 \%$ paraformaldehyde solution for $10 \mathrm{~min}$ were permeabilized by BD FACS Permeabilizing Solution (BD Biosciences, San Jose, CA, USA) for $10 \mathrm{~min}$ at room temperature. After washing with staining buffer (phosphate-buffered saline containing $0.5 \%$ bovine serum albumin), cells were stained with PE-conjugated anti-human Bcl-2 monoclonal antibody (code no. 340576, BD Biosciences). Flow cytometric analysis was performed using the Guava easyCyte ${ }^{\mathrm{TM}} 8 \mathrm{HT}$ system (Merck Millipore, Darmstadt, Germany).

Chemosensitivity assay. Cells were seeded in 96-well plates at $2 \times 10^{3}$ cells/well and pre-cultured for $24 \mathrm{~h}$. Cells were treated with various concentrations of chemotherapeutic agents for $72 \mathrm{~h}$. At the end of the culture period, the cells were trypsinized, and absolute cell number was counted with Guava easyCyte $^{\mathrm{TM}}$ 8HT.

Cell viability assay. Cell viability was evaluated using the [3-(4, 5-dimethylthiazol-2-yl)-5-(3-carboxymethoxyphenyl)-2-(4-sulfophenyl)-2H-tetrazolium, inner salt (MTS)] (CellTiter $96^{\circledR}$ Aqueous One Solution Cell Proliferation assay, Promega, Madison, WI, USA). Briefly, cells were seeded in 96-well plates at $2 \times 10^{3}$ cells/well. Twenty-four hours later, the cells were treated with the indicated drugs. At the end of treatment, MTS solution was added to each well, and the plates were incubated for 1-3 h. The plates were read at a wavelength of $490 \mathrm{~nm}$ using a microplate reader (Infinite ${ }^{\mathrm{TM}}$ M1000, Tecan, Männedorf, Switzerland).

Fluorescence microscopy. Cells were seeded in 96-well plates at $2 \times 10^{3}$ cells/well after pre-culture for $24 \mathrm{~h}$. Then, the cells were treated with the indicated drugs. After treatment, Hoechst 33342 (Dojindo, Kumamoto, Japan) and 7-aminoactinomycin D (7-AAD, AnaSpec, Fremont, CA, USA) were added to the cells to a final concentration of 5 and $2.5 \mu \mathrm{g} / \mathrm{ml}$, respectively. Morphological changes of nuclei and cell death were evaluated under fluorescence microscopy after incubation at $37^{\circ} \mathrm{C}$ for $1 \mathrm{~h}$.

Caspase-3/7 activity assay. The caspase- 3 and -7 activities of cells were measured using Amplite ${ }^{\mathrm{TM}}$ Fluorimetric Caspase-3/7 assay kits (AAT Bioquest, Sunnyvale, CA, USA) according to the manufacturer's protocol. Briefly, cells were seeded in 384-well plates at $2.5 \times 10^{3}$ cells/well after pre-culture for $24 \mathrm{~h}$. After treatment, caspase-3/7 assay solution was added, and the cells were incubated for $1 \mathrm{~h}$ at room temperature. Cleavage substrate fluorescence was measured by a microplate reader, Infinite M1000 (Ex/Em = 350/450 nm).

Xenograft mouse model. Male Balb/c nu/nu mice were obtained from CLEA Japan (Tokyo, Japan). Bcl-2-overexpressing or control DU145 cells were inoculated subcutaneously into the flank at $2 \times 10^{6}$ cells. Docetaxel $(12 \mathrm{mg} / \mathrm{kg})$, cisplatin $(5 \mathrm{mg} / \mathrm{kg})$, or TNF- $\alpha(125 \mu \mathrm{g} / \mathrm{kg})$ was then administered intravenously once a week for 3 weeks, starting 3 weeks after inoculation. The tumor volume was estimated by using the following equation: $\mathrm{V}=\mathrm{ab}^{2} / 2$, where $\mathrm{a}$ and $\mathrm{b}$ are the tumor length and width, respectively. The present animal study was approved by the Ethics Committee of Sawai Pharmaceuticals.

Statistical analysis. Statistical analysis was carried out using the statistical program EXSUS (ver. 8.0.1, CAC EXICARE, Tokyo, Japan). $\mathrm{IC}_{50}$ values (concentrations required to inhibit cell viability by $50 \%$ ) were calculated with a sigmoid 
concentration-response model. The statistical significance of differences between two groups was assessed with Student's t-test, and Dunnett's test was used to compare multiple means with the control group. The data for $\mathrm{IC}_{50}$ values and logarithmic values of mean fluorescent intensity (MFI) of Bcl-2 expression levels were fitted by linear regression analysis, and correlation coefficients were calculated using Microsoft Excel 2010 (Seattle, WA, USA).

\section{Results}

Varied sensitivity of Bcl-2-expressing DU145 transfectants to anticancer drugs. Nine Bcl-2-expressing DU145 transfectants were established (Table I). The expression levels of Bcl-2 were measured by intracellular flow cytometry. Although the expression levels varied among the nine cell lines, line AA1 expressed Bcl-2 at the highest level. Representative results of flow cytometry of parental DU145, control DU145, and DU145-AA1 are shown in Fig. 1. Western blot analysis verified the expression of Bcl-2 protein as a molecular mass of $26 \mathrm{kDa}$, as predicted (data not shown). Next, the sensitivities of these transfectants to a panel of anticancer drugs were measured (Table I). The expression of Bcl-2 in DU145 cells did not correlate with the sensitivity to docetaxel or paclitaxel. The Bcl-2-overexpressing AA1 line was more sensitive to docetaxel than were control DU145, BA5, BB2, BD1, and G6 lines, all of which expressed Bcl-2 at lower levels. As for the sensitivities to the platinum-based anticancer agents cisplatin and carboplatin, the relation was unique. Some Bcl-2 transfectants were more sensitive to cisplatin and carboplatin than were the parental and control lines. However, the Bcl-2 overexpressing lines, such as AA1 and AD2, were less sensitive. In addition, Bcl-2 overexpression decreased their sensitivity to fluorouracil, but slightly increased their sensitivity to anthracyclines such as epirubicin and doxorubicin. Furthermore, the sensitivities of these transfectants to TNF- $\alpha$, which induces apoptosis via both intrinsic and extrinsic pathways, were also analyzed. Because TNF- $\alpha$ alone did not induce death in any cell line, TNF- $\alpha$-induced activity was enhanced by the addition of cycloheximide, a protein synthesis inhibitor. As a result, the sensitivity of DU145 transfectants to TNF- $\alpha$ strongly correlated with the Bcl-2 expression. Taken together, these results indicate that although the sensitivity of DU145 transfectants to TNF- $\alpha$ negatively correlated with Bcl-2 expression. A similar tendency was not observed when the transfectants were treated with docetaxel or other anticancer drugs.

Effects of Bcl-2 overexpression on in vivo sensitivity to docetaxel, cisplatin, and TNF- $\alpha$. Next, we examined whether overexpression of $\mathrm{Bcl}-2$ influenced the in vivo sensitivity of DU145 cells to docetaxel, cisplatin, and TNF- $\alpha$, using a xenograft mouse model. DU145-cont and DU145-AA1, which showed the highest expression of $\mathrm{Bcl}-2$, were transplanted to nude mice, which were then treated with the indicated drugs. In the vehicle-treated groups, there was no difference in tumor growth between DU145-cont and DU145-AA1, suggesting that the Bcl-2 expression level did not enhance the in vivo growth of DU145 cells. Treatment with docetaxel, cisplatin, or TNF- $\alpha$ significantly inhibited the growth of DU145-cont cells as compared with the vehicle control (Fig. 2A). In contrast, 


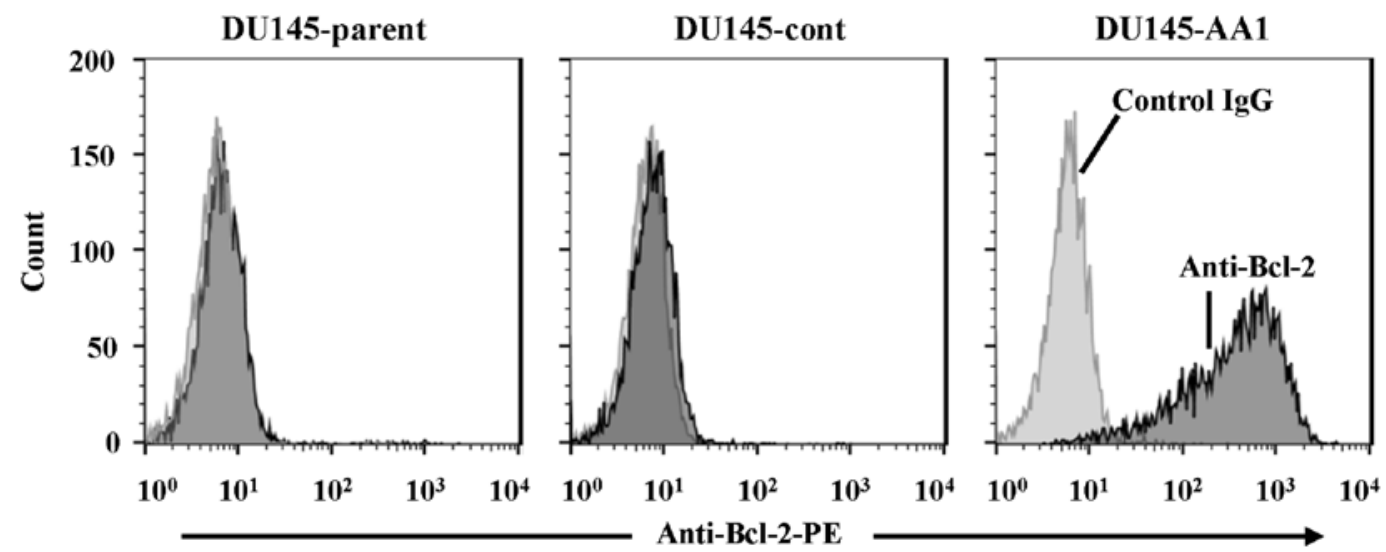

Figure 1. Flow cytometric analysis of Bcl-2 expression in parental, control, and Bcl-2-transfected DU145 cells. The Bcl-2 expression in parental DU145 cells (DU145-parent), control vector-transfectant cells (DU145-cont), and Bcl-2-transfectant cells (DU145-AA1) was measured by intracellular flow cytometry after staining with PE-conjugated anti-Bcl-2 antibody or mouse IgG isotype control.
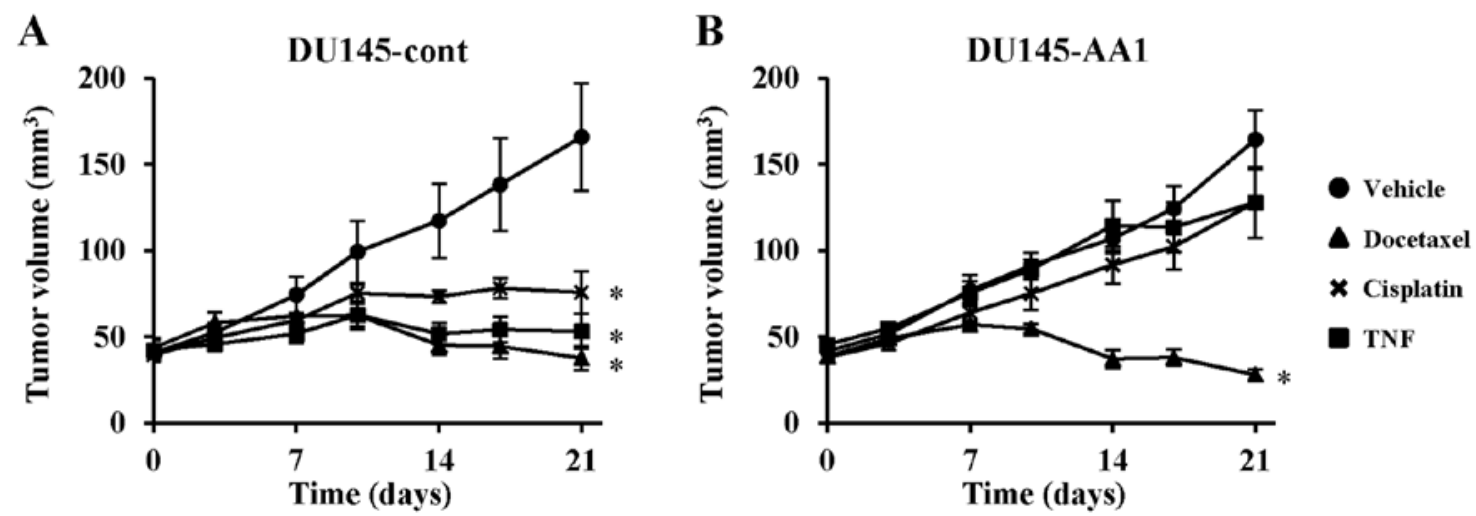

Figure 2.In vivo sensitivities of DU145-cont and DU145-AA1 cells to docetaxel, cisplatin, or TNF- $\alpha$. DU145-cont (A) and Bcl-2-overexpressing DU145-AA1 (B) cells were inoculated subcutaneously into the flank of nude mice. Docetaxel $(12 \mathrm{mg} / \mathrm{kg})$, cisplatin $(5 \mathrm{mg} / \mathrm{kg})$, or TNF- $\alpha(125 \mu \mathrm{g} / \mathrm{kg}) \mathrm{was}$ administered intravenously once a week for 3 weeks, starting 3 weeks after inoculation. Each group consisted of 6 or 7 mice. Tumor volume ( \pm SE) was measured for 3 weeks. ${ }^{*} \mathrm{P}<0.05$ by Dunnett's test, as compared with the vehicle-treated control group at experiment completion.

docetaxel suppressed the growth of DU145-AA1 cells, whereas neither cisplatin nor TNF- $\alpha$ inhibited tumor growth (Fig. 2B). These results indicate that the Bcl-2 expression level significantly influenced the in vivo sensitivity of DU145 cells to cisplatin and TNF- $\alpha$, but was unrelated to the sensitivity to docetaxel.

Cell death and morphological changes in DU145 cells treated with docetaxel, cisplatin, or TNF- $\alpha$. We next compared the sensitivity of DU145-cont and DU145-AA1 cells to anticancer drugs by fluorescence microscopy. As shown in Fig. 3A, although no difference in their sensitivity to docetaxel was observed, the AA1 line was more resistant to cisplatin and TNF- $\alpha$ than was DU145-cont. Morphological changes, such as nuclear shrinkage and condensation, were observed in docetaxel-treated DU145-cont and DU145-AA1 cells (Fig. 3B). DU145-cont cells treated with cisplatin showed no typical apoptotic changes, but the nucleus was partially condensed. These morphological changes were not apparent in cisplatintreated DU145-AA1 cells. In sharp contrast, TNF- $\alpha$ strongly induced cell death and typical apoptotic morphological changes of nuclei in DU145-cont cells, whereas overexpression of Bcl-2 attenuated these changes. These results indicate that overexpression of Bcl-2 had no effect on the cytotoxicity of docetaxel in DU145 cells.

Caspase-3/7 activation in DU145 cells treated with docetaxel, cisplatin, or TNF- $\alpha$. It is well known that caspases play important roles in apoptotic cell death. Therefore, we measured activities of executioner caspase-3/7 in DU145 and LNCaP cells, the latter of which are known to undergo apoptosis in response to docetaxel (16). In the case of DU145-cont cells, docetaxel and cisplatin slightly activated caspase-3/7, whereas TNF- $\alpha$ rapidly activated caspase-3/7 (Fig. 4A). In contrast, no such activation was observed in DU145-AA1 cells treated with docetaxel, cisplatin, or TNF- $\alpha$ (Fig. 4B). In the case of LNCaP cells, caspase-3/7 was rapidly and strongly activated by either cisplatin or TNF- $\alpha$, whereas the level of docetaxel-induced activation of caspase-3/7 was low (Fig. 4C). These results indicate that overexpression of Bcl-2 could inhibit TNF- $\alpha$-induced caspase-3/7 activation in DU145 cells, whereas docetaxel could not trigger caspase-3/7 activation.

Roles of Bid and caspases in death of DU145 cells. Bid mediates crosstalk between intrinsic and extrinsic apoptotic pathways (19). Therefore, we determined whether inhibition of 

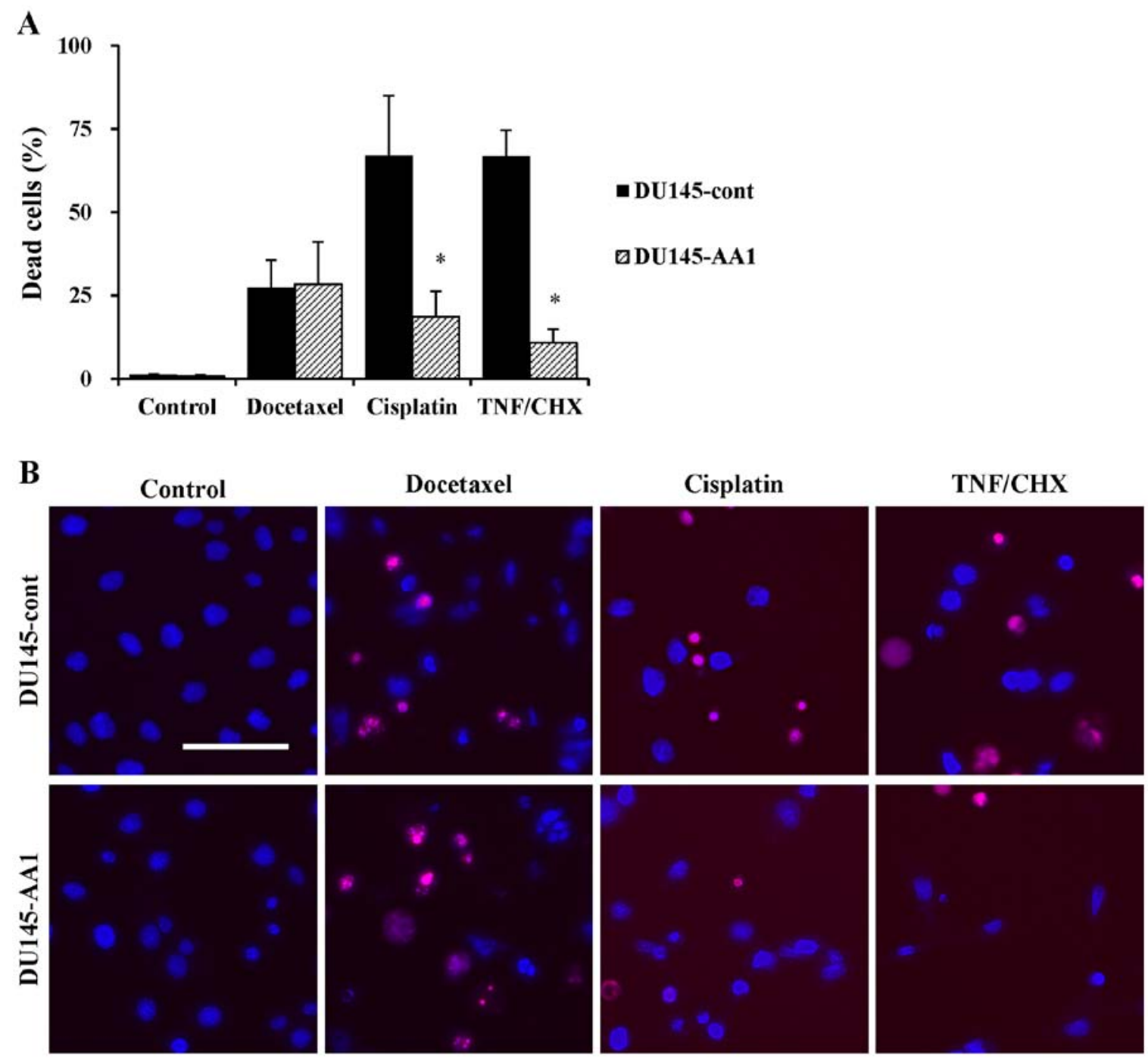

Figure 3. Cell death and morphological changes of DU145-cont and DU145-AA1 cells after treatment with docetaxel, cisplatin, or TNF- $\alpha$. (A) DU145-cont and DU145-AA1 cells were treated with docetaxel $(4 \mathrm{ng} / \mathrm{ml})$ for $48 \mathrm{~h}$, cisplatin $(4 \mu \mathrm{g} / \mathrm{ml})$ for $48 \mathrm{~h}$, or TNF- $\alpha(10 \mathrm{ng} / \mathrm{ml})$ and cycloheximide $(10 \mu \mathrm{g} / \mathrm{ml})$ (TNF/CHX) for $24 \mathrm{~h}$. After staining with Hoechst 33342 and 7-AAD, the percentages of dead cells were determined. 7-AAD-positive cells were counted at the end of each treatment, and the results are the means \pm SD of four replicates. ${ }^{*} \mathrm{P}<0.05$ by Student's t-test for the comparison between control and AA1 cells. (B) Representative results of fluorescence imaging are shown. Cells were stained with Hoechst 33342 (blue) and 7-AAD (red). The white scale bar represents $50 \mu \mathrm{m}$.
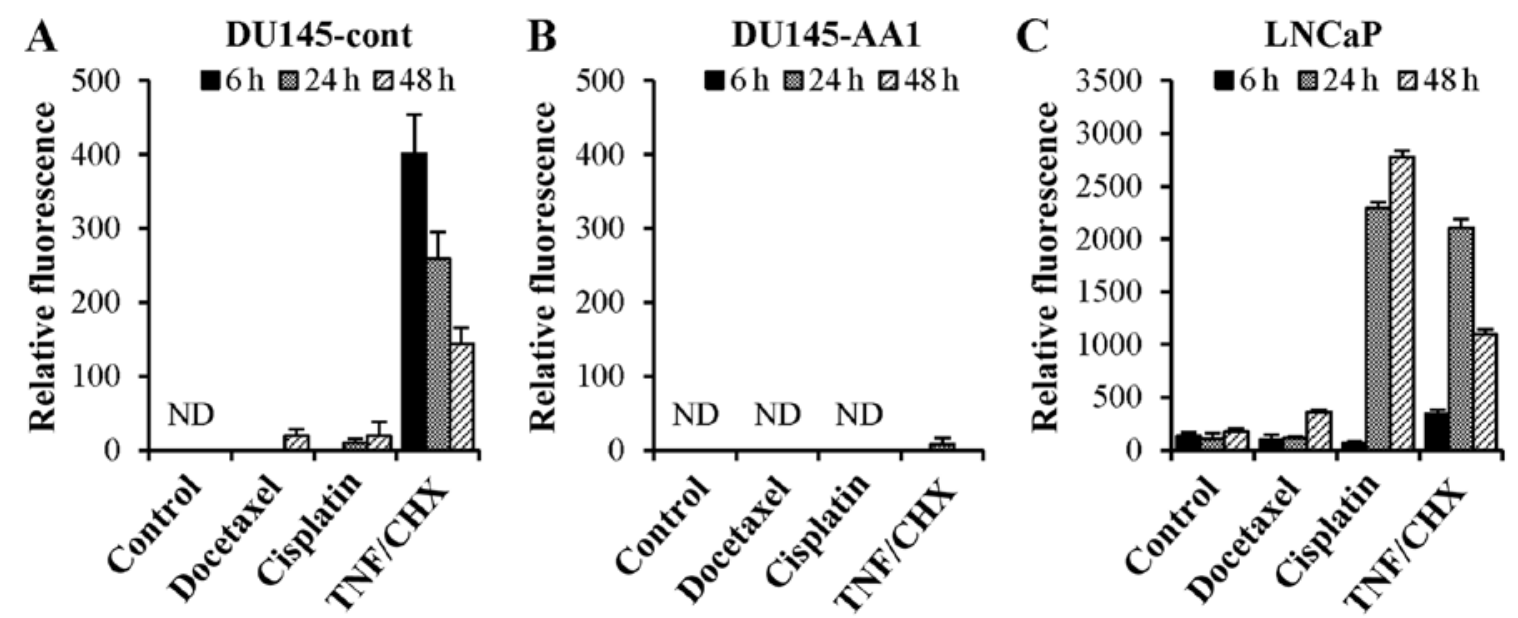

Figure 4. Caspase-3/7 activation in DU145-cont, DU145-AA1, and LNCaP cells after treatment with docetaxel, cisplatin, or TNF- $\alpha$. DU145-cont (A), DU145-AA1 (B), and LNCaP (C) cells were treated with docetaxel $(4 \mathrm{ng} / \mathrm{ml})$, cisplatin $(4 \mu \mathrm{g} / \mathrm{ml})$, or TNF- $\alpha(10 \mathrm{ng} / \mathrm{ml})$ and cycloheximide $(10 \mu \mathrm{g} / \mathrm{ml})$ (TNF/CHX) for 6, 24 and $48 \mathrm{~h}$. Thereafter, the activation levels of caspase-3 and -7 were measured. Data (mean \pm SD of triplicate determinations) represent one of two separate experiments that had similar results. ND, not detected. 

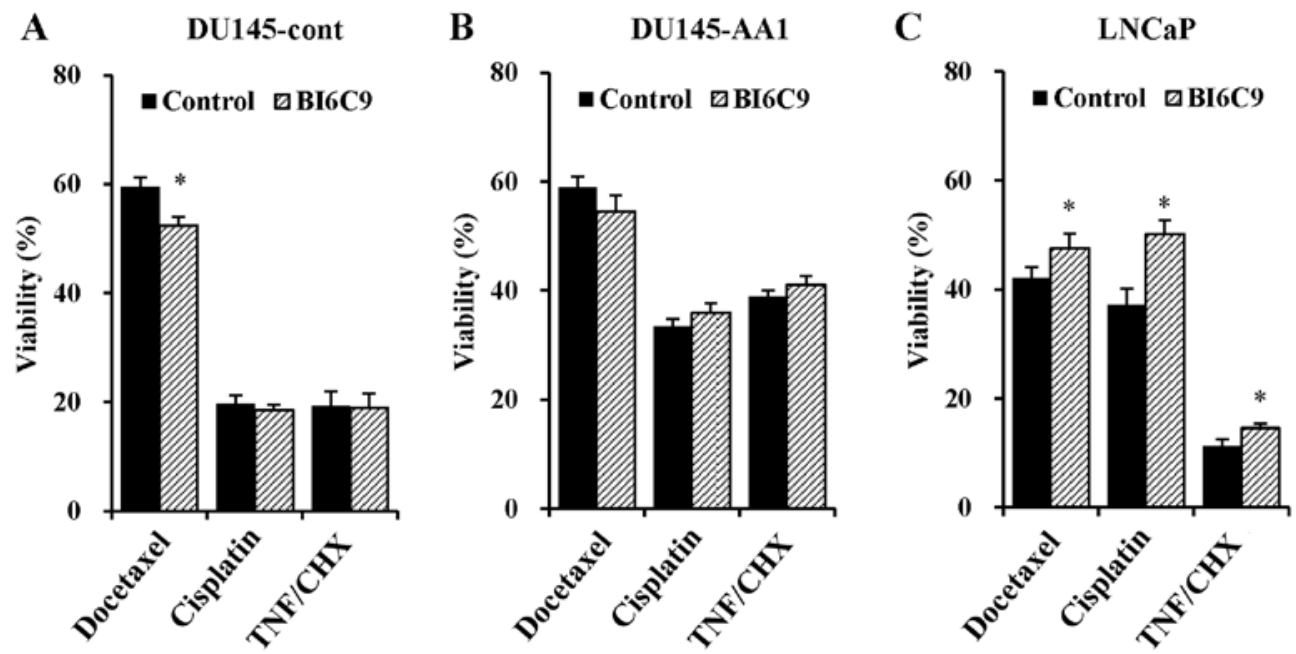

Figure 5. Effects of Bid inhibition on the sensitivity of DU145-cont, DU145-AA1, and LNCaP cells to docetaxel, cisplatin, or TNF- $\alpha$. After pretreatment with BI6C9 $(20 \mu \mathrm{M})$ for $30 \mathrm{~min}$, DU145-cont (A), DU145-AA1 (B), and LNCaP (C) cells were additionally treated with docetaxel (4 $\mathrm{ng} / \mathrm{ml})$ for $48 \mathrm{~h}$, cisplatin $(4 \mu \mathrm{g} / \mathrm{ml})$ for $48 \mathrm{~h}$, or TNF- $\alpha(10 \mathrm{ng} / \mathrm{ml})$ and cycloheximide $(10 \mu \mathrm{g} / \mathrm{ml})(\mathrm{TNF} / \mathrm{CHX})$ for $24 \mathrm{~h}$. Thereafter, the cell viability was determined. Data are means $\pm \mathrm{SD}$ of four independent experiments. "P<0.05 by Student's t-test for the comparison between with and without BI6C9 treatment.

Bid could rescue DU145 cells from death induced by docetaxel, cisplatin, or TNF- $\alpha$. The results showed that treatment with BI6C9, a specific inhibitor of Bid, did not preserve the viability of either DU145-cont or DU145-AA1 cells that were treated with docetaxel, cisplatin, or TNF- $\alpha$ (Fig. 5A and B). In contrast, treatment with $\mathrm{BI} 6 \mathrm{C} 9$ significantly preserved the viability of $\mathrm{LNCaP}$ cells treated with docetaxel, cisplatin, or TNF- $\alpha$ (Fig. 5C).

We further examined the contribution of caspase to the death of docetaxel-treated DU145 cells, using a panel of proapoptotic caspase inhibitors. Although none of the caspase inhibitors preserved the viability of docetaxel- or cisplatintreated DU145-cont cells, all of the inhibitors significantly preserved the viability of DU145-cont cells treated with TNF- $\alpha$ (Fig. 6A). In the case of DU145-AA1 cells, no such effect was observed (Fig. 6B). In contrast, only the pan-caspase inhibitor preserved the viability of docetaxel-treated $\mathrm{LNCaP}$ cells, and all inhibitors significantly preserved the viability of $\mathrm{LNCaP}$ cells treated with cisplatin or TNF- $\alpha$ (Fig. 6C). Overall, these results indicate that pro-apoptotic caspases were not involved in the death of docetaxel-treated DU145 cells.

\section{Discussion}

Although docetaxel has been the most useful chemotherapeutic agent for patients with prostate cancer, recurrent disease frequently becomes docetaxel-resistant. Therefore, in this study we attempted to determine roles of the anti-apoptotic molecule Bcl-2 in chemoresistance, using Bcl-2-expressing DU145 transfectants. Our results showed that Bcl-2 did not contribute to the docetaxel-resistance of DU145 cells and that their docetaxel-induced death is pro-apoptotic caspaseindependent.

TNF- $\alpha$ treatment induced activation of caspase- $3 / 7$ in control DU145 cells, whereas overexpression of Bcl-2 inhibited this activation (Fig. 4), indicating that TNF- $\alpha$ can induce caspase-dependent cell death in DU145 cells and that Bcl-2 acts as an anti-apoptotic molecule in this process. However, the rela- tion between $\mathrm{Bcl}-2$ expression and the susceptibility of cancer cells to docetaxel remains controversial. Previous studies have reported that abnormal Bcl-2 expression is involved in malignant alteration and chemoresistance $(24,27,28)$. On the other hand, suppression of Bcl-2 gene expression by siRNA has no effect on the anticancer activity of docetaxel in non-small cell lung cancer cells (30). Noguchi reported that clinical response of patients with breast cancer to docetaxel is unrelated to the Bcl-2 expression level (31). Therefore, we undertook this study.

In our study, docetaxel-induced caspase-3/7 activation was lower in DU145 cells than in LNCaP cells (Fig. 4), as previously reported by Liu et al (32). The underlying mechanism can be explained by $\mathrm{p} 53$, which is a transcription factor that responds to stress stimuli and induces pro-apoptotic Bcl-2 family members. DU145 cells and LNCaP cells carry mutated and wild-type p53, respectively. P53 mutation results in inactivation of caspases (33). In addition, pro-apoptotic Bax expression is much lower in DU145 cells than in LNCaP cells (34). Moreover, we observed that Bid inhibition could not restore the docetaxel-induced reduced viability of DU145 cells despite the fact that such inhibition increased the viability of LNCaP cells that were treated with docetaxel, cisplatin, or TNF- $\alpha$ (Fig. 5). Interestingly, a xenograft model showed that overexpression of Bcl-2 exerted no effect on the in vivo sensitivity of DU145 cells to docetaxel. On the basis of these findings, we suppose that the crucial death pathway of docetaxel-treated DU145 cells is independent of pro-apoptotic caspases and p53. If so, what kinds of cell death were induced in docetaxel-treated DU145 cells? Docetaxel induces activation of cathepsins (35), which are released from lysosome into the cytoplasm and subsequently induce a cascade of intracellular events. Cathepsins mediate release of cytochrome $c$ from mitochondria and amplify the intrinsic apoptosis cascade. Alternatively, cathepsins catalyze proteolytic degradation of substrates that are crucial for cell survival, leading to apoptosis (36). Perhaps cathepsin-mediated apoptosis occurred in Bcl-2 overexpressing DU145-AA1 cells. Furthermore, it has been shown that cytotoxic agents can trigger key events contributing to cell 

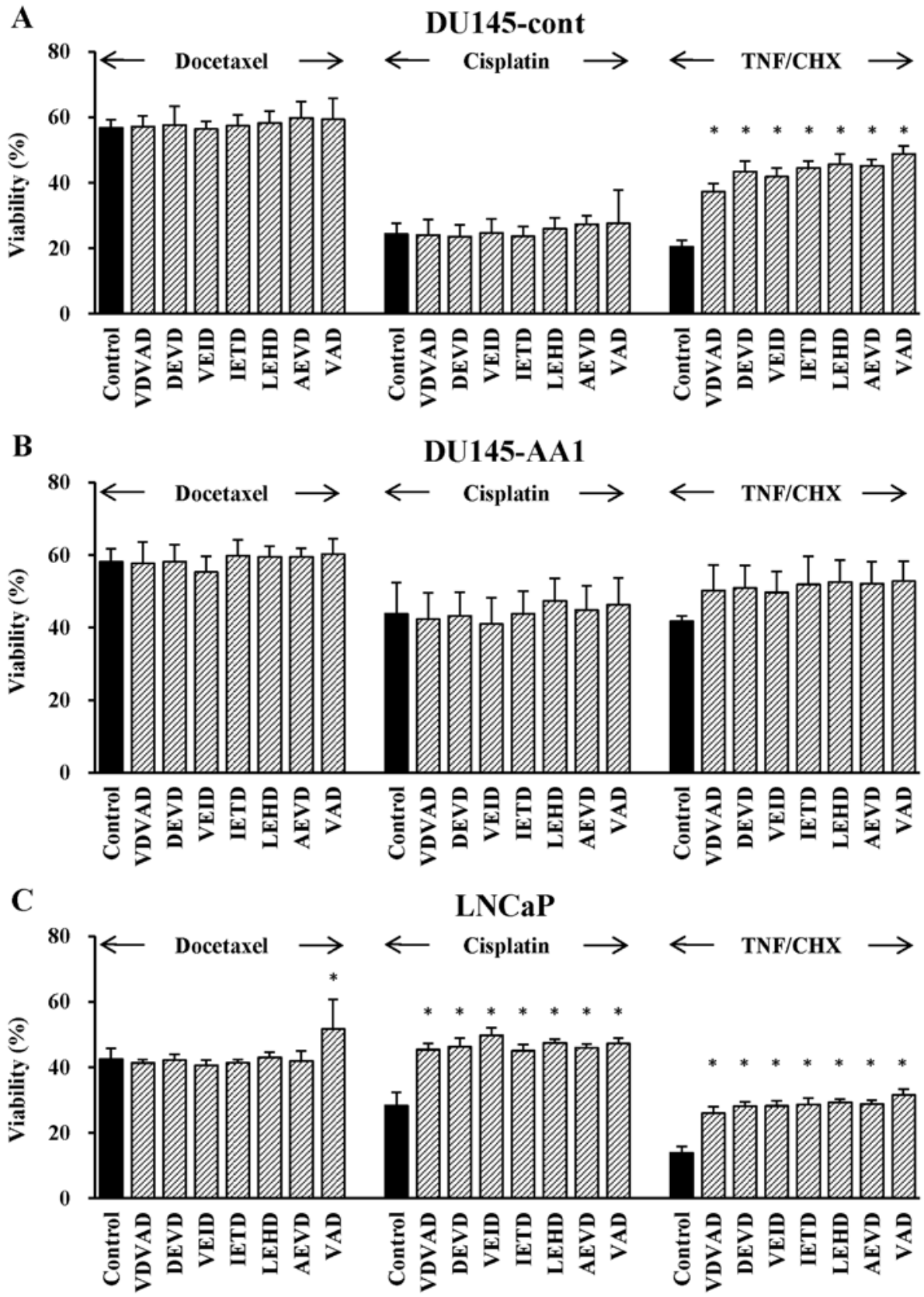

Figure 6. Effects of pro-apoptotic caspase inhibitors on the sensitivity of DU145-cont, DU145-AA1, and LNCaP cells to docetaxel, cisplatin, or TNF- $\alpha$. After pretreatment with a caspase inhibitor $(20 \mu \mathrm{M})$ for $30 \mathrm{~min}$, DU145-cont (A), DU145-AA1 (B), and LNCaP (C) cells were additionally treated with docetaxel $(4 \mathrm{ng} / \mathrm{ml})$ for $48 \mathrm{~h}$, cisplatin $(4 \mu \mathrm{g} / \mathrm{ml})$ for $48 \mathrm{~h}$, or TNF- $\alpha(10 \mathrm{ng} / \mathrm{ml})$ and cycloheximide $(10 \mu \mathrm{g} / \mathrm{ml})(\mathrm{TNF} / \mathrm{CHX})$ for $24 \mathrm{~h}$. The following caspase inhibitors of fluoromethyl ketone (FMK)-derivatized peptides were used: caspase-2, VDVAD; caspase-3/7, DEVD; caspase-6, VEID; caspase-8, IETD; caspase-9, LEHD; caspase-10, AEVD; and pan-caspase, VAD. Data are means \pm SD of four independent experiments. " $\mathrm{P}<0.05$ by Dunnett's test as compared with groups untreated with a caspase inhibitor.

survival or death, including necroptosis (37), autophagy (38), endoplasmic reticulum stress (39), and necrosis (40). Further studies are needed to elucidate the precise mechanisms that mediate the death of docetaxel-treated DU145 cells.

Interestingly, the sensitivities of control and Bcl-2expressing DU145 transfectants to chemotherapeutic agents other than docetaxel varied. The sensitivity to cisplatin fluctuated widely among the transfectants: some cell lines were sensitized, whereas other cell lines with higher levels of Bcl-2 were desensitized. Downregulation of Bcl-2 is associated with resistance to cisplatin in human small-cell lung cancer, but the underlying mechanisms remain unclear (41). Previous studies have reported that $\mathrm{Bcl}-2$ transfection modulates the expression and activity of Bim, a pro-apoptotic member (42). These results suggest that the sensitivity of cancer cells to cisplatin depends on the balance between the activities of anti- and pro-apoptotic $\mathrm{Bcl}-2$ family proteins. On the other hand, Bcl-2 transfection desensitized DU145 transfectants to fluorouracil, but slightly sensitized them to anthracyclines such as epirubicin and doxorubicin. It is very peculiar that the sensitivity to fluorouracil was inversely related to that of anthracyclines (correlation coefficient to epirubicin: -0.863 and doxorubicin: -0.735). In addition, Bcl-2 transfection slightly delayed proliferation (correlation coefficient: 0.314 ), and the relations of 
the doubling time to the sensitivities to fluorouracil and to anthracyclines were highly positive and moderately negative, respectively (correlation coefficient to fluorouracil: 0.918 , epirubicin: -0.762 and doxorubicin: -0.690). These results suggest that there may be a cross-correlation between the Bcl-2 expression level and the growth rate with respect to the sensitivity to fluorouracil and anthracyclines.

In conclusion, we investigated the effects of Bcl-2 expression in androgen-independent human prostate cancer DU145 cells on the susceptibility to docetaxel, as well as to cisplatin and TNF- $\alpha$. We also examined the effects of a panel of pro-apoptotic caspase inhibitors on the sensitivity of DU145 cells to docetaxel. Apoptosis is a hallmark of the anticancer activity of anticancer agents, and caspase-3/7 and Bcl-2 family proteins play central roles in the apoptosis pathway. However, our results indicate that $\mathrm{Bcl}-2$ expression does not necessarily contribute to the resistance of DU145 cells to docetaxel and that the docetaxel-induced death of DU145 cells is pro-apoptotic, and caspase-independent. Our data also indicate that the expression level of Bcl-2, which is a potent inhibitor of TNF- $\alpha$ induced apoptosis, may have no influence on the outcomes of patients with prostate cancer who receive docetaxel.

\section{Acknowledgements}

We thank Mr. Peter Star of Medical Network K.K. (Tokyo, Japan) for medical writing in the preparation of this manuscript.

\section{References}

1. Torre LA, Bray F, Siegel RL, Ferlay J, Lortet-Tieulent J and Jemal A: Global cancer statistics, 2012. CA Cancer J Clin 65: 87-108, 2015

2. Siegel R, Ward E, Brawley O and Jemal A: Cancer statistics, 2011: The impact of eliminating socioeconomic and racial disparities on premature cancer deaths. CA Cancer J Clin 61: 212-236, 2011.

3. Morgentaler A: Testosterone and prostate cancer: An historical perspective on a modern myth. Eur Urol 50: 935-939, 2006.

4. Huggins C and Hodges CV: Studies on prostatic cancer: I. The effect of castration, of estrogen and of androgen injection on serum phosphatases in metastatic carcinoma of the prostate. 1941. CA Cancer J Clin 22: 232-240, 1972.

5. Miyamoto H, Messing EM and Chang C: Androgen deprivation therapy for prostate cancer: Current status and future prospects. Prostate 61: 332-353, 2004.

6. Hammerer $\mathrm{P}$ and Madersbacher S: Landmarks in hormonal therapy for prostate cancer. BJU Int 110 (Suppl 1): 23-29, 2012.

7. Tannock IF, de Wit R, Berry WR, Horti J, Pluzanska A, Chi KN, Oudard S, Théodore C, James ND, Turesson I, et al; TAX 327 Investigators: Docetaxel plus prednisone or mitoxantrone plus prednisone for advanced prostate cancer. N Engl J Med 351: 1502-1512, 2004.

8. Petrylak DP, Tangen CM, Hussain MHA, Lara PNJ Jr, Jones JA, Taplin ME, Burch PA, Berry D, Moinpour C, Kohli M, et al: Docetaxel and estramustine compared with mitoxantrone and prednisone for advanced refractory prostate cancer. N Engl J Med 351: 1513-1520, 2004.

9. Sinibaldi VJ: Docetaxel treatment in the elderly patient with hormone refractory prostate cancer. Clin Interv Aging 2: 555-560, 2007.

10. Merseburger AS, Bellmunt J, Jenkins C, Parker C and Fitzpatrick JM; European Treatment Practices Group: Perspectives on treatment of metastatic castration-resistant prostate cancer. Oncologist 18: 558-567, 2013.

11. Sweeney CJ and Chamberlain D: Insights into E3805: The CHAARTED trial. Future Oncol 11: 897-899, 2015.

12. Fulda $\mathrm{S}$ and Debatin K-M: Extrinsic versus intrinsic apoptosis pathways in anticancer chemotherapy. Oncogene 25: 4798-4811, 2006.
13. Pienta KJ: Preclinical mechanisms of action of docetaxel and docetaxel combinations in prostate cancer. Semin Oncol 28 (Suppl 15): 3-7, 2001.

14. Stein CA: Mechanisms of action of taxanes in prostate cancer. Semin Oncol 26 (Suppl 17): 3-7, 1999.

15. Ganansia-Leymarie V, Bischoff P, Bergerat J-P and Holl V: Signal transduction pathways of taxanes-induced apoptosis. Curr Med Chem Anticancer Agents 3: 291-306, 2003.

16. Noguchi K, Shakuto S, Sakairi T and Yoshida Y: Decrease in prostate specific antigen secretion correlated with docetaxelinduced growth inhibition and apoptosis in human prostate tumor cells. Gan To Kagaku Ryoho 36: 1863-1870, 2009.

17. Green DR: Apoptotic pathways: Paper wraps stone blunts scissors. Cell 102: 1-4, 2000.

18. Kuwana T, Smith JJ, Muzio M, Dixit V, Newmeyer DD and Kornbluth S: Apoptosis induction by caspase- 8 is amplified through the mitochondrial release of cytochrome $c$. J Biol Chem 273: 16589-16594, 1998.

19. Green DR: Apoptotic pathways: The roads to ruin. Cell 94: 695-698, 1998.

20. Scaffidi C, Fulda S, Srinivasan A, Friesen C, Li F, Tomaselli KJ, Debatin KM, Krammer PH and Peter ME: Two CD95 (APO-1/ Fas) signaling pathways. EMBO J 17: 1675-1687, 1998.

21. Luo X, Budihardjo I, Zou H, Slaughter C and Wang X: Bid, a $\mathrm{Bcl} 2$ interacting protein, mediates cytochrome $c$ release from mitochondria in response to activation of cell surface death receptors. Cell 94: 481-490, 1998.

22. Li H, Zhu H, Xu CJ and Yuan J: Cleavage of BID by caspase 8 mediates the mitochondrial damage in the Fas pathway of apoptosis. Cell 94: 491-501, 1998.

23. Gross A, McDonnell JM and Korsmeyer SJ: BCL-2 family members and the mitochondria in apoptosis. Genes Dev 13: 1899-1911, 1999.

24. Yip KW and Reed JC: Bcl-2 family proteins and cancer. Oncogene 27: 6398-6406, 2008.

25. Johnson MI, Robinson MC, Marsh C, Robson CN, Neal DE and Hamdy FC: Expression of Bcl-2, Bax, and p53 in high-grade prostatic intraepithelial neoplasia and localized prostate cancer: Relationship with apoptosis and proliferation. Prostate 37: 223-229, 1998

26. Bubendorf L, Sauter G, Moch H, Jordan P, Blöchlinger A, Gasser TC and Mihatsch MJ: Prognostic significance of Bcl-2 in clinically localized prostate cancer. Am J Pathol 148: 1557-1565, 1996.

27. Brown JM and Wilson G: Apoptosis genes and resistance to cancer therapy: What does the experimental and clinical data tell us? Cancer Biol Ther 2: 477-490, 2003.

28. Srivastava RK, Sasaki CY, Hardwick JM and Longo DL: Bcl-2mediated drug resistance: Inhibition of apoptosis by blocking nuclear factor of activated T lymphocytes (NFAT)-induced Fas ligand transcription. J Exp Med 190: 253-265, 1999.

29. Inoue Y, Gika M, Abiko T, Oyama T, Saitoh Y, Yamazaki H, Nakamura M, Abe Y, Kawamura M and Kobayashi K: Bcl-2 overexpression enhances in vitro sensitivity against docetaxel in non-small cell lung cancer. Oncol Rep 13: 259-264, 2005.

30. Losert D, Pratscher B, Soutschek J, Geick A, Vornlocher H-P, Müller M and Wacheck V: Bcl-2 downregulation sensitizes nonsmall cell lung cancer cells to cisplatin, but not to docetaxel. Anticancer Drugs 18: 755-761, 2007.

31. Noguchi S: Predictive factors for response to docetaxel in human breast cancers. Cancer Sci 97: 813-820, 2006

32. Liu C, Zhu Y, Lou W, Nadiminty N, Chen X, Zhou Q, Shi XB, deVere White RW and Gao AC: Functional p53 determines docetaxel sensitivity in prostate cancer cells. Prostate 73: 418-427, 2013.

33. Gurova KV, Rokhlin OW, Budanov AV, Burdelya LG, Chumakov PM, Cohen MB and Gudkov AV: Cooperation of two mutant p53 alleles contributes to Fas resistance of prostate carcinoma cells. Cancer Res 63: 2905-2912, 2003.

34. Tamaki H, Harashima N, Hiraki M, Arichi N, Nishimura N, Shiina H, Naora K and Harada M: Bcl-2 family inhibition sensitizes human prostate cancer cells to docetaxel and promotes unexpected apoptosis under caspase-9 inhibition. Oncotarget 5: 11399-11412, 2014

35. Mediavilla-Varela M, Pacheco FJ, Almaguel F, Perez J, Sahakian E, Daniels TR, Leoh LS, Padilla A, Wall NR, Lilly MB, et al: Docetaxel-induced prostate cancer cell death involves concomitant activation of caspase and lysosomal pathways and is attenuated by LEDGF/p75. Mol Cancer 8: 68, 2009. 
36. Chwieralski CE, Welte T and Bühling F: Cathepsin-regulated apoptosis. Apoptosis 11: 143-149, 2006.

37. Delavallée L, Cabon L, Galán-Malo P, Lorenzo HK and Susin SA: AIF-mediated caspase-independent necroptosis: A new chance for targeted therapeutics. IUBMB Life 63: 221-232, 2011.

38. Yang ZJ, Chee CE, Huang S and Sinicrope FA: The role of autophagy in cancer: Therapeutic implications. Mol Cancer Ther 10: $1533-1541,2011$

39. Liao P-C, Tan S-K, Lieu C-H and Jung H-K: Involvement of endoplasmic reticulum in paclitaxel-induced apoptosis. J Cell Biochem 104: 1509-1523, 2008.
40. Jang M-S, Lee S-J, Kang NS and Kim E: Cooperative phosphorylation of FADD by Aur-A and Plk1 in response to taxol triggers both apoptotic and necrotic cell death. Cancer Res 71: 7207-7215, 2011.

41. Kumar Biswas S, Huang J, Persaud S and Basu A: Downregulation of $\mathrm{Bcl}-2$ is associated with cisplatin resistance in human small cell lung cancer H69 cells. Mol Cancer Ther 3: 327-334, 2004

42. Savry A, Carre M, Berges R, Rovini A, Pobel I, Chacon C, Braguer D and Bourgarel-Rey V: Bcl-2-enhanced efficacy of microtubule-targeting chemotherapy through Bim overexpression: Implications for cancer treatment. Neoplasia 15: 49-60, 2013. 